\title{
Creation of non-human primate neurogenetic disease models by gene targeting and nuclear transfer Robert B Norgren Jr*
}

\author{
Address: Department of Genetics, Cell Biology and Anatomy, University of Nebraska Medical Center, Omaha, Nebraska, USA \\ Email: Robert B Norgren* - rnorgren@unmc.edu \\ * Corresponding author
}

Published: 16 June 2004

Reproductive Biology and Endocrinology 2004, 2:40 doi:10.1 186/1477-7827-2-40

This article is available from: http://www.rbej.com/content/2/I/40

(c) 2004 Norgren; licensee BioMed Central Ltd. This is an Open Access article: verbatim copying and redistribution of this article are permitted in all media for any purpose, provided this notice is preserved along with the article's original URL.
Received: 12 March 2004

Accepted: 16 June 2004

\begin{abstract}
Genetically modified rhesus macaques are necessary because mouse models are not suitable for a number of important neurogenetic disorders; for example, Kallmann's syndrome, Lesch-Nyhan's disease and Ataxia-Telangiectasia. Mouse models may not be suitable because there may be no mouse ortholog of the human gene of interest, as is the case for Kallmann's syndrome, or because mutant mice do not exhibit the same phenotype observed in humans, as is the the case for LeschNyhan's disease and Ataxia-Telangiectasia. Non-human primate models of neurogenetic diseases are expected to more closely resemble human diseases than existing mouse models. Genetically modified rhesus macaques can be created by modifying the genome of a somatic cell and then transferring the nucleus from this cell to an enucleated oocyte. Random integration of a transgene is sufficient to create models of gain-of-function genetic diseases. Stable expression of green fluorescent protein has been achieved in rhesus macaque fibroblasts. However, gene targeting is necessary to create models of loss-of-function genetic diseases. Several technical challenges must be overcome before null mutant non-human primates can be produced. In our experience, fetal fibroblasts frequently become senescent before selection procedures can be completed. We have overcome this problem by transfecting somatic cells with human telomerase reverse transcriptase. This enzyme extends the telomeres, and lifespan, of somatic cells. Long and accurate polymerase chain reaction can be used to obtain sufficient regions of homology of isogenic rhesus genomic DNA for targeting constructs. This should improve gene targeting efficiency. Gene targeting experiments are currently underway. Null mutant rhesus macaques will likely result in breakthrough advances in the understanding of neurogenetic disease and prove invaluable for preclinical trials of new therapies.
\end{abstract}

\section{Review - The need for non-human primate models for neurogenetic diseases}

Although genetically modified mice have provided important new information about the function of many genes, there are serious limitations to current animal models for a number of neurogenetic diseases. One reason for this is that a mouse ortholog to a human gene of interest may not exist. It is estimated that between 0.5 -
$1 \%$ of human genes do not have mouse orthologs [1]. For example, no mouse ortholog has been identified for the KAL1 gene. Loss-of-function mutations in this gene cause Kallmann's syndrome, a neurodevelopmental disorder that results in anosmia and hypothalamic hypogonadism [2-5]. KAL1 is located in close proximity to pseudoautosomal region 1 (PAR1) and escapes X-inactivation [3,6-9]. Rearrangements in this region during rodent evolution 
may be the reason a mouse ortholog of KAL1 cannot be found $[10,11]$.

While mouse orthologs to genes involved in human diseases can usually be found, targeted mutations of these genes in mice may not result in any of the symptoms observed in humans with loss-of-function mutations in these genes. For example, the HPRT1 gene is mutated in Lesch-Nyhan's disease $[12,13]$. Symptoms include mental retardation, self-mutilation, choreoathetosis and spasticity. HPRT1 mutant mice do not exhibit the Lesch-Nyhan's disease phenotype [14]. It is interesting to note that HPRT1 was the first gene to be disrupted in mice $[15,16]$.

The most common problem with gene targeted mice is that they sometimes provide incomplete models of the human phenotype. For example, children with Ataxia-Telangiectasia (due to mutations in the ATM gene) exhibit ataxia (due to neurodegeneration of the Purkinje cells of the cerebellum), increased incidence of cancer and immune system dysfunction [17-20]. Mice with mutations in the ATM gene exhibit increased incidence of cancer and immune system dysfunction, but not degeneration of the Purkinje neurons and ataxia [21-23]. Mouse models of Alzheimer's disease also exhibit some but not all of the symptoms of this disease [24-26].

Rhesus macaque models of neurogenetic diseases are particularly desirable because the organization of the rhesus brain more closely resembles the human brain than does any non-primate brain. Monkey brains greatly exceed the size and complexity observed in mouse brains. As a consequence, rhesus macaques exhibit perceptual, cognitive and behavioral plasticity not observed in mice [27-29]. Neurological disorders may require novel therapeutic methods, such as gene therapy, which contain significant risks [30-32]. The availability of non-human primate (NHP) models will be essential to guarantee safety and efficacy of these new treatment options.

\section{A new approach to genetic modification in mammals}

The key to successful gene targeting in mice has been the availability of embryonic stem (ES) cells [15,33-39]. These cells have two important characteristics which facilitate genetic modification: 1 . They are immortal and can therefore be propagated indefinitely in cell culture, and 2 . They are totipotent and can therefore be used to create chimeric animals [38-40]. Some of these chimeric animals will contain germ cells derived from genetically modified ES cells. Breeding of chimeric animals can thus result in offspring in which every cell is genetically modified.

Although ES cells have been derived in several mammalian species (including rhesus macaques), such cells have not yet been used to create gene-targeted animals [41-47]. Murine ES cells appear to have especially favorable characteristics for gene targeting. The lack of ES cells with the same favorable attributes has limited progress in developing non-murine mammalian genetic models of human disease. However, even if such cells were available, the requirement that chimeric animals be bred to produce animals with the genetic modification in all cells would mean that it would take at least 5 years to produce a heterozygote (since macaques do not breed until they are 45 years old) [48]. Breeding to produce homozygotes would require at least 10 years.

The recent development of nuclear transfer techniques to create animals (whole animal cloning) has made it possible to perform gene targeting in mammals other than mice (sheep and pigs) [49-54]. The basic idea is to perform gene targeting in somatic cells and to then transfer the nuclei of these genetically modified cells to enucleated oocytes. The resulting embryos are then transferred to a surrogate mother. The animal that develops from this embryo should contain the genetic modification in every cell of its body. Application of this approach to rhesus macaques could be used to create NHP models of neurogenetic disease.

\section{Gene/disease selection}

Given the difficulty associated with generating a gene-targeted rhesus macaque, it is important to have a set of criteria for disease/gene selection. Our criteria are as follows: 1. Mutation in the gene should cause a serious human disease 2. No complete mouse model should be available 3 . The phenotype should be apparent early in the lifespan of rhesus macaque. We are currently working on three genes/ diseases that meet these criteria: HPRT1/Lesch-Nyhan's disease, KAL1/ Kallmann's syndrome and ATM/ataxia telangiectasia.

Lesch-Nyhan's disease is a neurodevelopmental disorder that is caused by loss-of-function mutations in the HPRT1 gene [12]. HPRT1 is located on chromosome X. As a result, most individuals affected by this disease are males. The HPRT1 gene encodes hypoxanthine guanine phosphoribosyltransferase, an enzyme involved in purine metabolism. The link between loss of this enzyme and the mental retardation and self-injurious behavior observed in patients with Lesch-Nyhan's disease is currently not understood. The absence of any similar deficits in HPRT1 null mutant mice has hindered understanding and treatment of this disease [14].

Loss-of-function mutations in KAL1, located on chromosome $\mathrm{X}$, cause some forms of Kallmann's syndrome [3,4]. In patients with Kallmann's syndrome, the olfactory nerve is formed but does not enter the telencephalon, resulting 
in anosmia. Because gonadotropin releasing hormone (GnRH) neurons originate in the olfactory placode and migrate to the brain early in embryonic development with the olfactory nerve, GnRH neurons form, but do not enter the brain in Kallmann's syndrome patients [2]. As a result, these individuals do not undergo puberty. One hypothesis regarding KAL1 function is that it helps guide olfactory nerve axons, and the GnRH neurons associated with them, into the brain [55]. However, the absence of a mouse ortholog to human KAL1 makes interpretation of available studies problematical.

Ataxia-telangiectasia is a neurodegenerative disease that is initially observed in young children [56,57]. Loss-of-function mutations in ATM, located on chromosome 11, cause this disease [20]. ATM is a key player in responding to DNA double-strand breaks [18]. Patients with ATM are at increased risk of cancer. Although ATM null mutant mice have been helpful in understanding the role of ATM in cancer, the failure of these animals to exhibit the loss of Purkinje cells of the cerebellum seen in patients has hindered an understanding of how mutations in ATM result in neurodegeneration. Perhaps as a result, little progress has been made in treating the neurological symptoms of this disease [58].

\section{Random integration of transgenes}

Some neurogenetic diseases are due to gain-of-function mutations. Random integration of a deleterious transgene into the rhesus genome would be sufficient to create effective animal models for these types of disease. Examples of gain-of-function mutations include CAG trinucleotide repeat disorders, such as Huntington's disease and spinal cerebellar ataxia 3. In these diseases, the trinucleotide CAG (which codes for gluatmine) is repeated to a greater extent than in unaffected individuals. The long stretches of polyglutamine observed in the relevant proteins are thought to be toxic to neurons [59]. Some forms of Alzheimer's disease and Parkinson's disease are also due to gain-of-function mutations [60,61]. However, many gainof-function neurodegenerative diseases take decades to develop in humans, and would probably take many years to develop in rhesus macaque genetic models.

Random integration of transgenes to create transgenic animals may be accomplished in several ways. One approach is to introduce the transgene into germ cells followed by fertilization. Rhesus macaque sperm were mixed with a plasmid containing a green fluorescent protein (GFP) reporter construct and injected into oocytes [62]. The developing embryos expressed GFP but the one healthy newborn did not [62]. A retroviral vector has been used to introduce a GFP expression cassette into a rhesus macaque oocyte which was subsequently fertilized in vitro [63]. RT-
PCR indicated that the animal expressed GFP mRNA; GFP protein was not observed [63].

Transgenes can also be introduced randomly into early embryos. Lentiviral infection of rhesus blastocysts has been used to introduce a GFP expression vector [64]. GFP expression was observed in the placenta, but not in the somatic tissues of the newborns [64]. An Epstein-Barr virus-based episomal vector has been injected into the pronuclei of rhesus embryos [65]. Blastocyst-stage embryos were shown to express GFP with this technique [65].

One disadvantage of introducing transgenes into germ cells or early embryos is that selection for stable expression of the transgene is not possible. Another approach is to introduce transgenes into somatic cells, select for stable expression of the transgene, and then transfer the nuclei of such cells to enucleated oocytes. We have observed stable expression of GFP in rhesus fibroblasts after transfection with a reporter construct. Such cells could be used to create transgenic macaques using nuclear transfer.

\section{Gene targeting in rhesus macaque fibroblasts - problems and solutions}

Although random integration of a transgene into the rhesus genome would be useful for creating models for a small number of diseases, many neurological disorders are due to loss-of-function mutations. Examples include Kallmann's syndrome, some forms of mental retardation (e. g. Lesch-Nyhan's disease), ataxia (e. g. Ataxia-Telangiectasia), deafness, blindness and some forms of Parkinson's disease $[3,4,12,13,18,19,66-69]$. Gene targeting will be necessary to create animal models for these diseases. Gene targeting is much more difficult to achieve than random integration of constructs.

There are four major barriers to gene targeting in somatic cells: Senescence, lack of isogenic DNA libraries, the impracticality of crosses to get homozygotes, and inefficient gene targeting.

Somatic cells, unlike ES cells, are mortal $[70,71]$. This is a problem for gene targeting as the necessary steps (transfection, selection and screening) require a significant number of population doublings $[54,72]$. In our experience, rhesus fibroblasts frequently become senescent during the time in vitro required for gene targeting. One solution to this problem is the use of human telomerase reverse transcriptase (hTERT). hTERT reverse transcribes telomerase RNA (TR) to extend telomeres [73-75]. The erosion of telomeres during cell division causes senescence in some cell types [75-77]. TERT expression is the rate limiting step in telomere extension [73]. TERT expression has been shown to immortalize fibroblasts, retinal 
pigmented epithelial cells, endothelial cells, keratinocytes, mammary epithelial cells and osteoblasts [78-85]. Importantly, transfection of hTERT constructs has been shown to extend the lifespan of rhesus fibroblasts indefinitely [86,87]. Further, although there are other methods for immortalizing cells, only TERT immortalizes without transforming cells $[81,85,88,89]$. This is important for our approach as an entire animal will be generated from the nucleus of the cell transferred to the enucleated oocyte.

The unique properties of TERT make it an ideal reagent for extending the lifespan of fibroblasts to permit gene-targeting. However, constitutive TERT expression may alter gene expression in somatic cells [90]. Because the phenotypic effects of constitutive TERT expression in a primate are unknown, it is important that construct-derived TERT only be expressed in cell culture. Constitutive TERT expression in sheep embryos created by nuclear transfer did not interfere with blastocyst formation, implantation or early embryonic development but may have interfered with fetal development [91]. To avoid deleterious effects of constitutive expression of TERT on fetal development, construct-derived TERT could be removed with the Crelox system prior to nuclear transfer. Alternatively, TERT could be expressed in cell culture, during selection and screening procedures, under the control of an inducible promoter.

There is general agreement that the use of isogenic DNA in gene targeting vectors improves targeting efficiency $[92,93]$ (although see [94] for a different opinion). For inbred strains of mice, acquiring isogenic genomic DNA is quite easy as genomic BAC libraries from the same strain used to create null mutants is available. Recently, a rhesus BAC genomic library has been constructed by Pieter de Jong and colleagues http://bacpac.chori.org/ rhesus250.htm. However, during the development of null mutant rhesus macaque technology, different cell types derived from different animals will be investigated for efficiency of gene-targeting and nuclear transfer. It is impractical to create a BAC library for each animal used. Thus, another method must be used to acquire homologous genomic sequence. The use of long and accurate PCR provides a solution to this problem. Primers can be designed that will consistently amplify genomic fragments sufficiently long to create targeting vectors. A PCRbased approach provides considerable flexibility as homologous DNA can rapidly be obtained from cells of different animals facilitating the construction of new, isogenic targeting vectors.

Homozygotes are required to observe a phenotype for many loss-of-function diseases. However, rhesus macaques do not breed until they are 4-5 years old [48]. Thus, producing homozygotes would take a minimum of
5 years using breeding. One way to avoid this wait is to target X-linked recessive genes in XY cells. In this case, it will only be necessary to disrupt one allele to see a phenotype. For autosomal recessive genes, it will still be necessary to disrupt two copies of a gene. This can be accomplished by successive rounds of gene targeting [95]. The use of TERT-lifespan-extended cells makes this approach practical.

Gene targeting is very inefficient in comparison with random integration of constructs, even in mouse embryonic stem cells. How efficient is gene targeting in rhesus fibroblasts likely to be? Since gene targeting has been achieved in fibroblasts for several species, including humans, it is instructive to consider rates of success in these species. The first report of gene targeting in fibroblasts followed by nuclear transfer occurred in sheep [53]. A very high level of gene targeting efficiency was observed using Lipofectamine for transfection [53]. In contrast, low levels of gene targeting efficiency were observed in sheep, pig and human fibroblasts using electroporation for transfection $[50,51,54,96]$. The reported high efficiency of gene targeting with Lipofectamine in sheep fibroblasts is surprising given that chemical methods have been shown to be a poor method for gene targeting both in mouse and human ES cells $[97,98]$. For this reason, electroporation is the gene targeting method of choice for ES cells $[97,98]$. Our preliminary results suggest that the high levels of success obtained in sheep fibroblasts with Lipofectamine are unlikely to be obtained with rhesus fibroblasts. Our expectation is that electroporation will be necessary to achieve gene targeting, but that efficiency is likely to be quite low [72].

Given an expected low efficiency of gene targeting, it is important to design experiments to maximize chances of success. For example, it is expected that large numbers of cells will be required. Fortunately, TERT life span extension means that unlimited numbers of cells are available for experimentation. The length of homology is another variable which may influence success in gene targeting $[15,99]$. We have been able to obtain homologous sequence of at least $9 \mathrm{~kb}$ for each of the three genes we plan to disrupt. This should be a sufficient length of homology to construct good targeting vectors. Because gene targeting is an infrequent event in comparison to random integration of the targeting construct, enrichment for targeting events is desirable. This can be achieved through the use of promoterless neomycin resistance cassettes $[100,101]$. With these constructs, expression of neomycin resistance is contingent upon integration within a gene. Since the genic region only constitutes $3 \%$ of the genome, most random integrants will be selected against. All genetically modified animals created from the transfer of the nucleus of a gene-targeted somatic cell have been 
created using promoterless vectors $[50,51,54,96]$. Gene targeting in human somatic cells is also conducted with promoterless vectors $[102,103]$. One caveat with this approach is that the gene to be targeted must be expressed in the cells being used, as it is the promoter from the targeted gene which will drive expression of the neomycin resistance cassette. Fortunately, each of the three genes we plan to disrupt are expressed in rhesus fibroblasts.

Not all gene targeting events result in functional disruption of the gene of interest. Given the expense and time involved in creating rhesus macaques through nuclear transfer, it is desirable to be as certain as possible that functional disruption of a targeted gene has been achieved prior to nuclear transfer. One advantage of targeting the HPRT1 gene is that functional selection can be applied. Specifically, only cells that do not express HPRT1 can survive selection with 6-thioguanine (6TG) [104]. Since HPRT1 is located on chromosome $\mathrm{X}$, transfection of a HPRT1 targeting vector in XY cells will result in 6TG-resistant cells only if the HPRT1 gene is functionally disrupted. Any cells that continue to express functional HPRT1 after transfection will be killed by 6TG. Thus, it will be possible to produce cells that have been verified to have no HPRT1 function.

Other approaches may improve gene targeting in NHPs still further. For example, allthough infrequently used, relatively high levels of gene targeting have been achieved with adenovirus vectors [105]. Gene targeting in somatic cells has been recently shown to be dramatically improved with two experimental protocols: 1 . thymidine block of cell replication and 2. including a SV40 enhancer sequence in the targeting construct [106]. Thymidine treatment has been shown to induce homologous, but not nonhomologous, recombination [107]. A 72 bp fragment from the SV40 enhancer improves import of plasmids into cell nuclei [108]. This sequence apparently allows plasmids to bind to transcription factors which are transported to the nucleus via nucleus localization signals [108]. The combination of thymidine treatment and the presence of the SV40 enhancer sequence in the targeting construct allowed Mir and Piedrahita to obtain a ratio of homologous recombination to random integration of the construct of 1:3 after electroporating bovine fetal fibroblasts [106]. It is notewothy that they achieved this phenomenal gene targeting rate with a construct that did contain a promoter driving expression of the selection cassette.

\section{Summary and future directions}

The production of genetically modified rhesus macaques poses a number of serious challenges. The first step is to produce genetically modified cells (Table 1 ). We have achieved random integration of a construct and stable expression of GFP. The more difficult feat of gene targeting is expected to be greatly facilitated by extending the lifespan of somatic cells with hTERT. Thymidine treatment and improved nuclear import of targeting constructs with SV40 enhancer sequence may also substantially improve gene targeting in rhesus macaque somatic cells. A number of rhesus ES cell lines have been derived. Some of these may prove useful in gene targeting experiments. The problems associated with nuclear transfer from somatic cells are currently being tackled. Experience with rhesus embryonic and human somatic cells suggests that there is no unsolvable barrier to whole animal cloning in primates [109-112]. Solving the various challenges to producing genetically modified macaques is well worth the effort as null mutant NHPs will likely result in breakthrough advances in the understanding of neurogenetic disease and prove invaluable for preclinical trials of new therapies.

Table I: Procedural steps in producing a genetically modified rhesus macaque

\begin{tabular}{ll}
\hline I. & Isolate isogenic genomic fragments using long and accurate \\
2. & PCR \\
3. & Transtruct targeting construct \\
4. & Select and identify targeted clones \\
5. & Remove TERT \\
6. & Nuclear transfer \\
7. & Embryo transfer \\
8. & Analysis of genetically modified NHP \\
\hline
\end{tabular}

\section{References}

I. Waterston RH, Lindblad-Toh K, Birney E, Rogers J, Abril JF, Agarwal $\mathrm{P}$, Agarwala R, Ainscough R, Alexandersson M, An P, Antonarakis SE, Attwood J, Baertsch R, Bailey J, Barlow K, Beck S, Berry E, Birren B, Bloom T, Bork P, Botcherby M, Bray N, Brent MR, Brown DG, Brown SD, Bult C, Burton J, Butler J, Campbell RD, Carninci P, Cawley S, Chiaromonte F, Chinwalla AT, Church DM, Clamp M, Clee C, Collins FS, Cook LL, Copley RR, Coulson A, Couronne O, Cuff J, Curwen V, Cutts T, Daly M, David R, Davies J, Delehaunty KD, Deri J, Dermitzakis ET, Dewey C, Dickens NJ, Diekhans M, Dodge S, Dubchak I, Dunn DM, Eddy SR, Elnitski L, Emes RD, Eswara P, Eyras E, Felsenfeld A, Fewell GA, Flicek P, Foley K, Frankel WN, Fulton LA, Fulton RS, Furey TS, Gage D, Gibbs RA, Glusman G, Gnerre S, Goldman N, Goodstadt L, Grafham D, Graves TA, Green ED, Gregory S, Guigo R, Guyer M, Hardison RC, Haussler D, Hayashizaki Y, Hillier LW, Hinrichs A, Hlavina W, Holzer T, Hsu F, Hua A, Hubbard T, Hunt A, Jackson I, Jaffe DB, Johnson LS, Jones M, Jones TA, Joy A, Kamal M, Karlsson EK, Karolchik D, Kasprzyk A, Kawai J, Keibler E, Kells C, Kent WJ, Kirby A, Kolbe DL, Korf I, Kucherlapati RS, Kulbokas EJ, Kulp D, Landers T, Leger JP, Leonard S, Letunic I, Levine R, Li J, Li M, Lloyd C, Lucas S, Ma B, Maglott DR, Mardis ER, Matthews L, Mauceli E, Mayer JH, McCarthy M, McCombie WR, McLaren S, McLay K, McPherson JD, Meldrim J, Meredith B, Mesirov JP, Miller W, Miner TL, Mongin E, Montgomery KT, Morgan M, Mott R, Mullikin JC, Muzny DM, Nash WE, Nelson JO, Nhan MN, Nicol R, Ning Z, Nusbaum C, O'Connor MJ, Okazaki Y, Oliver K, Overton-Larty E, Pachter L, Parra G, Pepin KH, Peterson J, Pevzner P, Plumb R, Pohl CS, Poliakov A, Ponce TC, Ponting CP, Potter S, Quail M, Reymond A, Roe BA, Roskin KM, Rubin EM, Rust AG, Santos R, Sapojnikov V, Schultz B, Schultz J, Schwartz MS, Schwartz S, Scott C, Seaman S, Searle S, Sharpe T, Sheridan A, Shownkeen R, Sims S, Singer JB, Slater G, Smit A, Smith 
DR, Spencer B, Stabenau A, Stange-Thomann N, Sugnet C, Suyama M, Tesler G, Thompson J, Torrents D, Trevaskis E, Tromp J, Ucla C, Ureta-Vidal A, Vinson JP, Von Niederhausern AC, Wade CM, Wall M, Weber RJ, Weiss RB, Wendl MC, West AP, Wetterstrand K, Wheeler R, Whelan S, Wierzbowski J, Willey D, Williams S, Wilson RK, Winter E, Worley KC, Wyman D, Yang S, Yang SP, Zdobnov EM, Zody MC, Lander ES: Initial sequencing and comparative analysis of the mouse genome. Nature 2002, 420:520-562.

2. Schwanzel-Fukuda M, Bick D, Pfaff DW: Luteininzing hormonereleasing hormone (LHRH)-expressing cells do not migrate normally in an inherited hypogonadal (Kallmann) syndrome. Mol Brain Res 1989, 6:311-326.

3. Franco B, Guioli S, Pragliola A, Incerti B, Bardoni B, Tonlorenzi R, Carrozzo R, Maestrini E, Pieretti M, Taillon-Miller P, Brown C], Willard HF, Lawrence C, Persico MG, Camerino G, Ballabio A: A gene deleted in Kallmann's syndrome shares homology with neural cell adhesion and axonal path-finding molecules. Nature I99|, 353:529-536.

4. Legouis R, Hardelin JP, Levilliers J, Claverie J-M, Compain S, Wunderle V, Millasseau P, Le Paslier D, Cohen D, Caterina D, Bougueleret $L$, Delemarre-Van de Waal H, Lutfalla G, Weissenbach J, Petit C: The candidate gene for the $X$-linked Kallmann syndrome encodes a protein related to adhesion molecules. Cell I99I, 67:423-435.

5. Bick D, Curry CJ, McGill JR, Schorderet DF, Bux RC, Moore CM: Male infant with ichthyosis, Kallmann syndrome, chondrodysplasia punctata, and an Xp chromosome deletion. Am J Med Genet 1989, 33:100-107.

6. Ross MT, Ballabio A, Craig IW: Long-range physical mapping around the human steroid sulfatase locus. Genomics 1990, 6:528-539.

7. Petit C, Levilliers J, Weissenbach J: Long-range restriction map of the terminal part of the short arm of the human $X$ chromosome. Proc Natl Acad Sci USA 1990, 87:3680-3684.

8. Johnson CL, Charmley P, Yen PH, Shapiro LJ: A multipoint linkage map of the distal short arm of the human $X$ chromosome. Am J Hum Genet I991, 49:261-266.

9. Incerti B, Guioli S, Pragliola A, Zanaria E, Borsani G, Tonlorenzi R, Bardoni B, Franco B, Wheeler D, Ballabio A, et-al: Kallmann syndrome gene on the $X$ and $Y$ chromosomes: implications for evolutionary divergence of human sex chromosomes. Nat Genet 1992, 2:31।-314.

10. Gianfrancesco F, Sanges R, Esposito T, Tempesta S, Rao E, Rappold G Archidiacono N, Graves JA, Forabosco A, D'Urso M: Differentia divergence of three human pseudoautosomal genes and their mouse homologs: implications for sex chromosome evolution. Genome Res 200I, I I:2095-2 I00.

II. Ellison JW, Li X, Francke U, Shapiro LJ: Rapid evolution of human pseudoautosomal genes and their mouse homologs. Mamm Genome 1996, 7:25-30.

12. Nyhan WL: The recognition of Lesch-Nyhan syndrome as an inborn error of purine metabolism. J Inherit Metab Dis 1997, 20:17|-178.

13. Jinnah HA, De Gregorio L, Harris JC, Nyhan WL, O'Neill JP: The spectrum of inherited mutations causing HPRT deficiency: $\mathbf{7 5}$ new cases and a review of 196 previously reported cases. Mutat Res 2000, 463:309-326.

14. Engle SJ, Womer DE, Davies PM, Boivin G, Sahota A, Simmonds HA, Stambrook PJ, Tischfield JA: HPRT-APRT-deficient mice are not a model for lesch-nyhan syndrome. Hum Mol Genet 1996, 5:1607-1610

15. Thomas KR, Capecchi MR: Site-directed mutagenesis by gene targeting in mouse embryo-derived stem cells. Cell 1987, $51: 503-512$

16. Doetschman T, Maeda N, Smithies O: Targeted mutation of the Hprt gene in mouse embryonic stem cells. Proc Natl Acad Sci 1988, 85:8583-8587.

17. Gumy-Pause F, Wacker P, Sappino AP: ATM gene and lymphoid malignancies. Leukemia 2004, 18:238-242.

18. Shiloh Y: ATM and related protein kinases: safeguarding genome integrity. Nat Rev Cancer 2003, 3:155-168.

19. Crawford TO, Mandir AS, Lefton-Greif MA, Goodman SN, Goodman BK, Sengul H, Lederman HM: Quantitative neurologic assessment of ataxia-telangiectasia. Neurology 2000, 54:I505-1509.

20. Savitsky K, Bar-Shira A, Gilad S, Rotman G, Ziv Y, Vanagaite L, Sfez S, Ashkenazi M, Pecker I, Frydman m., Harnik R, Patanjali SR, Simmons
A, Clines GA, Sartiel A, Gatti RA, Chessa L, Sanal O, Lavin MF, Jaspers NGJ, Taylor AMR, Arlett CF, Miki T, Weissman SM, Lovett M, Collins FS, Shiloh Y: A single ataxia telangiectasia gene with a product similar to PI-3 kinase. Science 1995, 268:1749-1753.

21. Barlow C, Hirotsune S, Paylor R, Liyanage M, Eckhaus M, Collins F, Shiloh Y, Crawley JN, Ried T, Tagle D, Wynshaw-Boris A: Atm-deficient mice: A paradigm of Ataxia telangiectasia. Cell 1996, 86:|59-|7|

22. Xu Y, Ashley T, Brainerd EE, Bronson RT, Meyn MS, Baltimore D: Targeted disruption of ATM leads to growth retardation, chromosomal fragmentation during meiosis, immune defects, and thymic lymphoma. Genes Dev 1996, 10:24 I I-2422.

23. Elson A, Wang Y, Daugherty CJ, Morton CC, Zhou F, CamposTorres J, Leder P: Pleiotropic defects in ataxia-telangiectasia protein-deficient mice. Proc Natl Acad Sci, USA 1996, 93:13084-II389.

24. Davis S, Laroche $\mathrm{S}$ : What can rodent models tell us about cognitive decline in Alzheimer's disease? Mol Neurobiol 2003, 27:249-276.

25. Phinney AL, Horne P, Yang J, Janus C, Bergeron C, Westaway D: Mouse models of Alzheimer's disease: the long and filamentous road. Neurol Res 2003, 25:590-600.

26. Dodart JC, Mathis C, Bales KR, Paul SM: Does my mouse have Alzheimer's disease? Genes Brain Behav 2002, I: I 42-155.

27. Voytko ML, Tinkler GP: Cognitive function and its neural mechanisms in nonhuman primate models of aging, Alzheimer disease, and menopause. Front Biosci 2004, 9:1899-1914.

28. Barr CS, Newman TK, Becker ML, Parker CC, Champoux M, Lesch KP, Goldman D, Suomi SJ, Higley JD: The utility of the non-human primate; model for studying gene by environment interactions in behavioral research. Genes Brain Behav 2003, 2:336-340.

29. Tootell RB, Tsao D, Vanduffel W: Neuroimaging weighs in: humans meet macaques in "primate" visual cortex. J Neurosci 2003, 23:398I-3989.

30. Stephenson J: Studies illuminate cause of fatal reaction in gene-therapy trial. JAMA 200I, 285:2570.

3I. Ye X, Mitchell M, Newman K, Batshaw ML: Prospects for prenatal gene therapy in disorders causing mental retardation. Ment Retard Dev Disabil Res Rev 200I, 7:65-72.

32. Zanjani ED, Anderson WF: Prospects for in utero human gene therapy. Science 1999, 285:2084-2088.

33. Evans M, Hunter S: Source and nature of embryonic stem cells. 2002, 325:1003-1007.

34. Capecchi MR: Generating mice with targeted mutations. Nat Med 200I, 7:1086-1090.

35. Doetschman TC: Gene targeting in embryonic stem cells. Biotechnology 1991, 16:89-101.

36. Hooper ML: Embryonal Stem Cells. Introducing Planned Changes into the Animal Genome. Chur, Switzerland, Harwood Academic; 1992.

37. Hooper M, Hardy K, Handyside A, Hunter S, Monk M: HPRT-deficient (Lesch-Nyhan) mouse embryos derived from germline colonization by cultured cells. Nature 1987, 326:292-295.

38. Martin GR: Isolation of a pluripotent cell line from early mouse embryos cultured in medium conditioned by teratocarcinoma stem cells. Proc Natl Acad Sci U S A 198I, 78:7634-7638.

39. Evans MJ, Kaufman MH: Establishment in culture of pluripotential cells from mouse embryos. Nature 198I, 292: 154-156.

40. Brinster RL: The effect of cells transferred into the mouse blastocyst on subsequent development. J Exp Med 1974, 140:1049-1056.

4I. Mitalipov SM, Kuo HC, Hennebold JD, Wolf DP: Oct-4 expression in pluripotent cells of the rhesus monkey. Biol Reprod 2003, 69:1785-1792.

42. Evans MJ, Notarieanni E, Laurie S, Moor RM: Derivation and preliminary characterization of pluripotent cell lines from porcine and bovine blastocysts. Theriogenology 1990, 33: | 25- I 28.

43. Wheeler MB: Development and validation of swine embryonic stem cells: a review. Reprod Fertil Dev 1994, 6:563-568.

44. Thomson JA, Marshall VS: Primate embryonic stem cells. Curr Top Dev Biol 1998, 38:। 33-165.

45. Stranzinger GF: Embryonic stem-cell-like cell lines of the species rat and Bovinae. Int J Exp Pathol 1996, 77:263-267.

46. Stice SL, Strelchenko NS, Keefer CL, Matthews L: Pluripotent bovine embryonic cell lines direct embryonic development following nuclear transfer. Biol Reprod 1996, 54:100-II0. 
47. Thomson JA, Kalishman J, Golos TG, Durning M, Harris CP, Becker RA, Hearn JP: Isolation of a primate embryonic stem cell line. Proc Natl Acad Sci USA 1995, 92:7844-7848.

48. Hendrickx AG, Dukelow WR: Reproductive biology. Nonhuman Primates in Biomedical Research: Biology and Management Edited by: Bennett B T, Christian R A and Hendrickson R. San Diego, Academic Press; 1995:|47-19|.

49. Phelps CJ, Koike C, Vaught TD, Boone J, Wells KD, Chen SH, Ball S, Specht SM, Polejaeva IA, Monahan JA, Jobst PM, Sharma SB, Lamborn AE, Garst AS, Moore M, Demetris AJ, Rudert WA, Bottino R, Bertera S, Trucco M, Starzl TE, Dai Y, Ayares DL: Production of alpha I,3galactosyltransferase-deficient pigs. Science 2003, 299:4 | |-4|4

50. Dai Y, Vaught TD, Boone J, Chen SH, Phelps CJ, Ball S, Monahan JA Jobst PM, McCreath KJ, Lamborn AE, Cowell-Lucero JL, Wells KD, Colman A, Polejaeva IA, Ayares DL: Targeted disruption of the alphal,3-galactosyltransferase gene in cloned pigs. Nat Biotechnol 2002, 20:25I-255.

5I. Lai L, Kolber-Simonds D, Park KW, Cheong HT, Greenstein JL, Im GS, Samuel M, Bonk A, Rieke A, Day BN, Murphy CN, Carter DB, Hawley RJ, Prather RS: Production of \{alpha\}-I,3-Galactosyltransferase Knockout Pigs by Nuclear Transfer Cloning. Science 2002, epub ahead of print:.

52. Denning C, Burl S, Ainslie A, Bracken J, Dinnyes A, Fletcher J, King T, Ritchie M, Ritchie WA, Rollo M, de Sousa P, Travers A, Wilmut I, Clark AJ: Deletion of the alpha $(I, 3)$ galactosyl transferase (GGTAI) gene and the prion protein (PrP) gene in sheep. Nat Biotechnol 200I, 1 9:559-562.

53. McCreath KJ, Howcroft J, Campbell KHS, Colman A, Schnieke AJ, Kind AJ: Production of gene-targeted sheep by nuclear transfer from cultured somatic cells. Nature 2000, 405: I066-1069.

54. Denning C, Dickinson P, Burl S, Wylie D, Fletcher J, Clark AJ: Gene targeting in primary fetal fibroblasts from sheep and pig. Cloning Stem Cells 2001, 3:22I-23I.

55. MacColl G, Bouloux P, Quinton R: Kallmann syndrome: adhesion, afferents, and anosmia. Neuron 2002, 34:675-678.

56. Becker-Catania SG, Gatti RA: Ataxia-telangiectasia. Adv Exp Med Biol 2001, 495:191-198.

57. Crawford TO: Ataxia telangiectasia. Sem Ped Neurol 1998, 5:287-294

58. Perlman S, Becker-Catania S, Gatti RA: Ataxia-telangiectasia: diagnosis and treatment. Semin Pediatr Neurol 2003, I 0: I73-182.

59. La Spada AR, Taylor JP: Polyglutamines placed into context. Neuron 2003, 38:68I-684.

60. Selkoe DJ: Amyloid beta-protein and the genetics of Alzheimer's disease. I Biol Chem 1996, 27 I: 18295-18298.

6I. Polymeropoulos MH, Lavedan C, Leroy E, Ide SE, Dehejia A, Dutra A, Pike B, Root H, Rubenstein J, Boyer R, Stenroos ES, Chandrasekharappa S, Athanassiadou A, Papapetropoulos T, Johnson WG, Lazzarin AM, Duvoisin RC, Di lorio G, Golbe LI, Nussbaum RL: Mutation in the alpha-synuclein gene identified in families with Parkinson's disease. Science 1997, 276:2045-2047.

62. Chan AW, Luetjens CM, Dominko T, Ramalho-Santos J, Simerly CR, Hewitson L, Schatten G: Foreign DNA transmission by ICSI: injection of spermatozoa bound with exogenous DNA results in embryonic GFP expression and live rhesus monkey births. Mol Hum Reprod 2000, 6:26-33

63. Chan AWS, Chong KY, Martinovich C, Simerly C, Schatten G: Transgenic monkeys produced by retroviral gene transfer into mature oocytes. Science 2001, 29 I:309-312.

64. Wolfgang MJ, Eisele SG, Browne MA, Schotzko ML, Garthwaite MA, Durning M, Ramezani A, Hawley RG, Thomson JA, Golos TG: Rhesus monkey placental transgene expression after lentiviral gene transfer into preimplantation embryos. Proc Natl Acad Sci U S A 200I, 98:10728-10732.

65. Wolfgang MJ, Marshall VS, Eisele SG, Schotzko ML, Thomson JA, Golos TG: Efficient method for expressing transgenes in nonhuman primate embryos using a stable episomal vector. Mol Reprod Dev 2002, 62:69-73.

66. Bitner-Glindzicz $M$ : Hereditary deafness and phenotyping in humans. Br Med Bull 2002, 63:73-94.

67. Graw J: The genetic and molecular basis of congenital eye defects. Nat Rev Genet 2003, 4:876-888.

68. Bonifati V, Rizzu P, van Baren MJ, Schaap O, Breedveld G], Krieger E Dekker MC, Squitieri F, Ibanez P, Joosse M, van Dongen JW, Vanacore N, van Swieten JC, Brice A, Meco G, van Duijn CM, Oostra BA Heutink P: Mutations in the DJ-I gene associated with auto- somal recessive early-onset parkinsonism. Science 2003, 299:256-259.

69. Kitada T, Asakawa S, Hattori N, Matsumine $H$, Yamamura $Y$, Minoshima S, Yokochi M, Mizuno Y, Shimizu N: Mutations in the parkin gene cause autosomal recessive juvenile parkinsonism. Nature 1998, 392:605-608.

70. Houck JC, Sharma VK, Hayflick L: Functional failures of cultured human diploid fibroblasts after continued population doublings. Proc Soc Exp Biol Med I97I, I 37:33 I-333.

7I. Hayflick L: The limited in vitro lifetime of human diploid cell strains. Exp Cell Res 1965, 37:614.

72. Williams SH, Sahota V, Palmai-Pallag T, Tebbutt SJ, Walker J, Harris $A$ : Evaluation of gene targeting by homologous recombination in ovine somatic cells. Mol Reprod Dev 2003, 66: I I 5 - I 25.

73. Weinrich SL, Pruzan R, Ma L, Ouellette M, Tesmer VM, Holt SE, Bodnar AG, Lichtsteiner S, Kim NW, Trager JB, Taylor RD, Carlos R, Andrews WH, Wright WE, Shay JW, Harley CB, Morin GB: Reconstitution of human telomerase with the template RNA component $h$ TR and the catalytic protein subunit hTRT. Nat Genet 1997, I 7:498-502.

74. Keith WN, Bilsland A, Evans TR, Glasspool RM: Telomerasedirected molecular therapeutics. Expert Rev Mol Med 2002, 2002: I-25.

75. Counter CM: The roles of telomeres and telomerase in cell life span. Mutat Res 1996, 366:45-63.

76. Harley CB, Vaziri H, Counter CM, Allsopp RC: The telomere hypothesis of cellular aging. Exp Gerontol 1992, 27:375-382.

77. Allsopp RC, Harley CB: Evidence for a critical telomere length in senescent human fibroblasts. Exp Cell Res 1995, 21 9:130-136.

78. Chang WL, Kirchoff V, Pari GS, Barry PA: Replication of rhesus cytomegalovirus in life-expanded rhesus fibroblasts expressing human telomerase. J Virol Methods 2002, I 04: I 35- I 46.

79. Yudoh K, Matsuno H, Nakazawa F, Katayama R, Kimura T: Reconstituting telomerase activity using the telomerase catalytic subunit prevents the telomere shorting and replicative senescence in human osteoblasts. J Bone Miner Res 2001, I 6: | 453.

80. Steinert S, Shay JW, Wright WE: Transient expression of human telomerase extends the life span of normal human fibroblasts. Biochem Biophys Res Commun 2000, 273: 1095-1098.

8I. Ouellette MM, Liao M, Herbert BS, Johnson M, Holt SE, Liss HS, Shay JW, Wright WE: Subsenescent telomere lengths in fibroblasts immortalized by limiting amounts of telomerase. J Biol Chem 2000, 275: 10072-10076.

82. Bodnar AG, Ouellette M, Frolkis M, Holt SE Chiu CP, Morin GB, Harley $C B$, Shay JW, Lichtsteiner S, Wright WE: Extension of life-span by introduction of telomerase into normal human cells. Science 1998, 279:349-352.

83. Vaziri $\mathrm{H}$, Benchimol S: Reconstitution of telomerase activity in normal human cells leads to elongation of telomeres and extended replicative life span. Curr Biol 1998, 8:279-282.

84. Counter CM, Meyerson M, Eaton EN, Ellisen LW, Caddle SD, Haber DA, Weinberg RA: Telomerase activity is restored in human cells by ectopic expression of hTERT (hEST2), the catalytic subunit of telomerase. Oncogene 1998, 16:1217-1222.

85. Yang J, Chang E Cherry AM, Bangs CD, Oei Y, Bodnar A, Bronstein $A$, Chiu CP, Herron GS: Human endothelial cell life extension by telomerase expression. J Biol Chem 1999, 274:26|4|-26I48.

86. Steinert S, White DM, Zou Y, Shay JW, Wright WE: Telomere biology and cellular aging in non-human primate cells. Exp Cell Res 2002, 272:146-152.

87. Kirchoff V, Wong S, St JS, Pari GS: Generation of a life-expanded rhesus monkey fibroblast cell line for the growth of rhesus rhadinovirus (RRV). Arch Virol 2002, 147:32I-333.

88. Morales CP, Holt SE, Ouellette M, Kaur KJ, Yan Y, Wilson KS, White MA, Wright WE, Shay JW: Absence of cancer-associated changes in human fibroblasts immortalized with telomerase. Nat Genet 1999, 2 I: II5-II8.

89. Jiang $X R$, Jimenez G, Chang E, Frolkis M, Kusler B, Sage M, Beeche M, Bodnar AG, Wahl GM, Tlsty TD, Chiu CP: Telomerase expression in human somatic cells does not induce changes associated with a transformed phenotype. Nat Genet 1999 , 2I:III-II4.

90. Lindvall C, Hou M, Komurasaki T, Zheng C, Henriksson M, Sedivy JM, Bjorkholm M, Teh BT, Nordenskjold M, Xu D: Molecular characterization of human telomerase reverse transcriptase- 
immortalized human fibroblasts by gene expression profiling: activation of the epiregulin gene. Cancer Res 2003, 63: $1743-1747$.

9I. Cui W, Wylie D, Aslam S, Dinnyes A, King T, Wilmut I, Clark AJ: Telomerase-immortalized sheep fibroblasts can be reprogrammed by nuclear transfer to undergo early development. Biol Reprod 2003, 69:15-2I.

92. te Riele H, Maandag ER, Berns A: Highly efficient gene targeting in embryonic stem cells through homologous recombination with isogenic DNA constructs. Proc Natl Acad Sci U S A 1992, 89:5 I28-5। 32 .

93. Waldman AS, Liskay RM: Dependence of intrachromosomal recombination in mammalian cells on uninterrupted homology. Mol Cell Biol 1 988, 8:5350-5357.

94. Sedivy JM, Vogelstein B, Liber HL, Hendrickson EA, Rosmarin A: Gene targeting in human cells without isogenic DNA. Science 1999, 283:9a.

95. Hanson KD, Sedivy JM: Analysis of biological selections for highefficiency gene targeting. Mol Cell Biol 1995, I5:45-5I.

96. Brown JP, Wei W, Sedivy JM: Bypass of senescence after disruption of P2ICIPI/WAFI gene in normal diploid human fibroblasts. Science 1997, 277:83I-834.

97. Vasquez KM, Marburger K, Intody Z, Wilson JH: Manipulating the mammalian genome by homologous recombination. Proc Natl Acad Sci U S A 200I, 98:8403-8410.

98. Zwaka TP, Thomson JA: Homologous recombination in human embryonic stem cells. Nat Biotechnol 2003, 21:319-32I.

99. Hasty P, Rivera-Perez J, Bradley A: The length of homology required for gene targeting in embryonic stem cells. Mol Cell Biol 1991, I I:5586-559I.

100. Schwartzberg PL, Robertson EJ, Goff SP: Targeted gene disruption of the endogenous $\mathrm{c}-\mathrm{abl}$ locus by homologous recombination with DNA encoding a selectable fusion protein. Proc Natl Acad Sci USA 1990, 87:3210-3214.

I0I. Jeannotte L, Ruiz JC, Robertson EJ: Low level of Hoxl.3 gene expression does not preclude the use of promoterless vectors to generate a targeted gene disruption. Mol Cell Biol I991, I I:5578-5585.

102. Sedivy JM, Sharp PA: Positive genetic selection for gene disruption in mammalian cells by homologous recombination. Proc Natl Acad Sci USA 1989, 86:227-231.

103. Sedivy JM, Dutriaux A: Gene targeting and somatic cell genetics: a rebirth or a coming of age? Trends Genet 1999, I 5:88-90.

104. Cox R, Masson WK: The isolation and preliminary characterisation of 6-thioguanine-resistant mutants of human diploid fibroblasts. Mutat Res 1976, 36:93-104.

105. Fujita A, Sakagami K, Kanegae Y, Saito I, Kobayashi I: Gene targeting with a replication-defective adenovirus vector. J Virol 1995, 69:6180-6190

106. Mir B, Piedrahita JA: Nuclear localization signal and cell synchrony enhance gene targeting efficiency in primary fetal fibroblasts. Nucleic Acids Res 2004, 32:e25.

107. Lundin C, Erixon K, Arnaudeau C, Schultz N, Jenssen D, Meuth M, Helleday T: Different roles for nonhomologous end joining and homologous recombination following replication arrest in mammalian cells. Mol Cell Biol 2002, 22:5869-5878.

108. Dean DA, Dean BS, Muller S, Smith LC: Sequence requirements for plasmid nuclear import. Exp Cell Res 1999, 253:7। 3-722.

109. Hwang WS, Ryu YJ, Park JH, Park ES, Lee EG, Koo JM, Chun HY, Lee BC, Kang SK, Kim SJ, Ahn C, Hwang JH, Park KY, Cibelli JB, Moon SY: Evidence of a Pluripotent Human Embryonic Stem Cell Line Derived from a Cloned Blastocyst. Science 2004.

110. Mitalipov SM, Yeoman RR, Nusser KD, Wolf DP: Rhesus monkey embryos produced by nuclear transfer from embryonic blastomeres or somatic cells. Biol Reprod 2002, 66: I367-1373.

11 I. Wolf DP, Meng L, Ouhibi N, Zelinski-Wooten M: Nuclear transfer in the Rhesus monkey: Practical and basic implications. Biol Reprod 1999, 60:199-204.

I 12. Meng L, Ely JJ, Stouffer RL, Wolf DP: Rhesus monkeys produced by nuclear transfer. Biol Reprod 1997, 57:454-459.

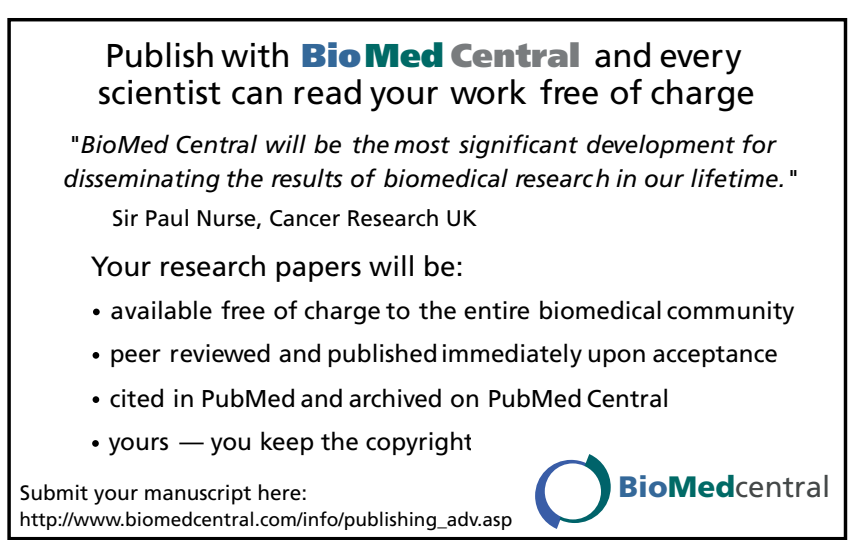

